Prediction Analysis of Trip Production
Using Cross-Classification Technique
Dr.Abdul Khalik Al-Taei
Amssistant Prof. Trans.Engineering
Civil Engineering Dept. /College of
Eng.
University of Dohuk

ABSTRACT

In this study a cross-classification technique is used to predict trip production travel among 20 traffic analysis zones located within Dohuk city residential area. Two and three level cross-classification matrices has been used to describe disaggregated trip rates/Du, total vehicle trips/Du and total private trips/Du. Car ownership is considered as the main factor causing trip production related to other household characteristics like family size income level and workers number.

Out of this study it is concluded that data can be used directly in the prediction analysis of trip rates. Family size and workers number are the most effective independent variables. Number of cells can be reduced if larger sample size are used in the prediction analysis as well.

Key Word : Cross Classification, Dohuk

\title{
rU゚+ ŤKE
}

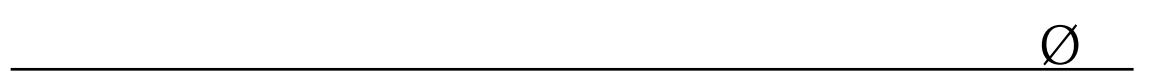
ta"

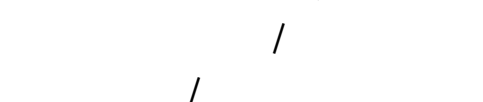

Bga' rî́s

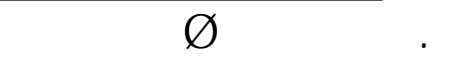

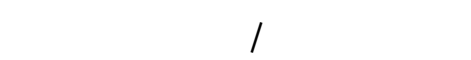

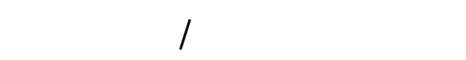

Bga' rî́s

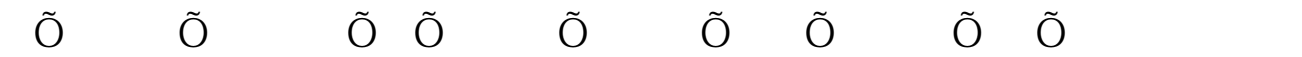

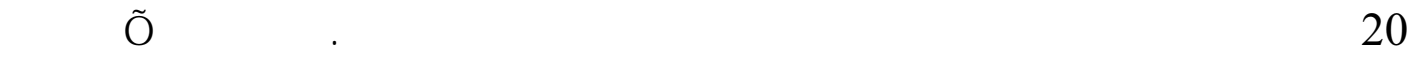

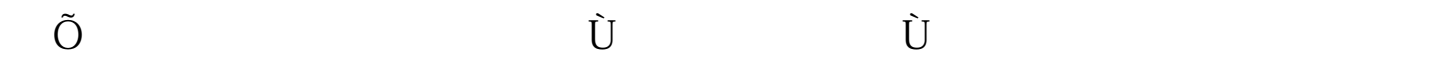

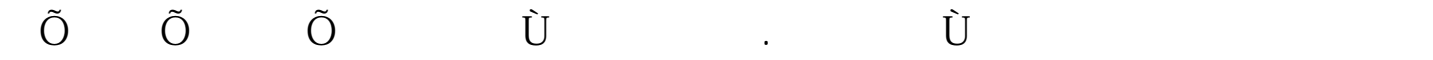

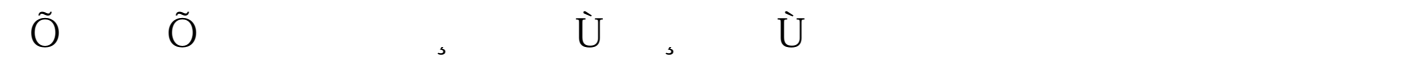

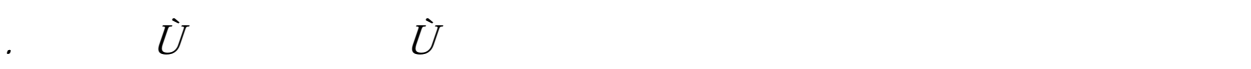

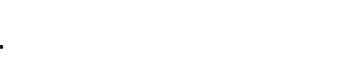

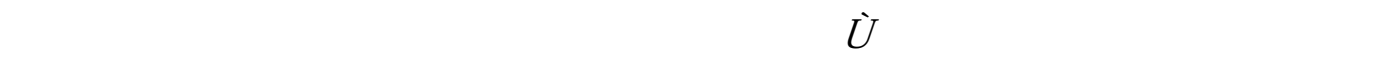

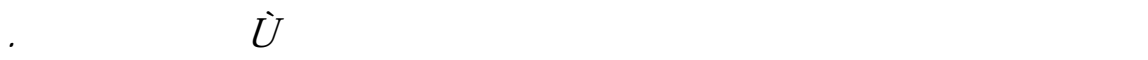

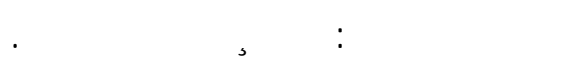




\begin{tabular}{llll} 
Al-Rafidain Engineering & Vol.14 & No.4 & 2006 \\
\hline
\end{tabular}

\section{Introduction}

Urban transportation planning is concerned with the development of transportation plan for an urban area in the process that leads to decisions on transportation policies and programs. This act required that an urbanized area of 50,000 or more in population be based on a continuing comprehensive urban transportation planning process (UTP) Which is the process of urban road network improvement planning after collection and analysis of socio-economic human travel characteristics to develop travel demand models required for the development of the above road network. This process can be carried out cooperatively by different authorities in the city headed by the local government ( 1 ).

Trip generation analysis and model development is one of the four step urban travel analysis and forecasting process recommended by the Bureau of Public Roads ( BPR ) During $1950 \mathrm{~s}$ ( 1 ). The forecasting process begins with an estimate of the variables that determine travel patterns including location and intensity of land use social economic characteristics of population and the type and extent of transportation facilities in the study area. These variables are used to estimate the number of trip origins and destinations in each sub- area of the city ( i.e, traffic analysis zone ) using trip generation procedure.

\section{Problem and Purpose}

Dohuk city is located in the northern part of Iraq. This special geographical location caused a lot of transportation to be executed though this city and other parts of Kurdistan provinces in the east like Erbil and Sulymania. Population community in Dohuk city is not more than 250,000 consisting mainly of the original residents of the city and other people who had migrated from different parts of the region. The standard of living for residents has grown gradually and a lot of people start to obtain car privately. Car ownership is growing positively especially during the last four years with the same road network. Congestion travel time delay of traffic high parking demand and high frequency of accidents are the natural results of this social and commercial development.

The main purpose of this study is to conduct a cross-classification analysis on a home interview survey data ( HIS ) from previous study to predict the travel pattern behavior of residents in the city related to their socio-economic and travel trend characteristics (2).This study is quite useful to forecast the future travel pattern to propose further developments.

\section{Study Area}

Dohuk city urban area was divided into 27 traffic analysis zones (3). Zone boundaries were modified according to the general rules for zone size selection and according to the information of the Central Statistics Office in Dohuk city. This plan was used in this study to select the most popular residential zones from which $85 \%$ of the trip productions are going to take place, twenty zones have been selected for this purpose. Figure ( 1 ) shows the master plan of Dohuk city and the zones selected (i.e., numbered zones) for this study. The other remaining seven zones are mostly commercial, business, medical, institutional and public service buildings. 


\section{Data Collection}

In this study the (HIS ) is used as it is considered as the best method to provide suitable and in-depth information about travel activity and behavior of citizens in each household ( 4 ).

HIS was conducted for ( 2437 ) families and necessary data was collected for this study as shown in table (1). Activities requiring travel were recorded for all household residents for a 24 hour period on the survey day which is the day before the day when questions had been collected that will be Sunday ,Monday, Tuesday, Wednesday and Thursday. An extensive form taken out from literature reviews was performed and concluded $(4,5,6)$.

The dwelling unit file was including the maximum amount of information pertaining to the whole household and have great effect on trip making such as:

1- Total number of persons living in the $\mathrm{HH}$;

2- Number of persons older than six years living in $\mathrm{HH}$;

3- Car-ownership;

4- Family income level;

5 - Number of workers in the $\mathrm{HH}$;

6- Number of employment in the HH;

7- Number of students in the $\mathrm{HH}$; and

8- Occupation of head of $\mathrm{HH}$.

A trip file was prepared that summarized all the expanded trip data recorded and a diary of travel by all household members age sex ....etc. A separate table for each mode of travel is completed showing the total number of trip purpose from origin to destination.

\section{Trip Classification}

All trips that either begin or end at the home of the trip maker are classified as Home Based Trips(HBT) while those that have neither beginning nor ending at the trip maker's place of residence are termed Non-Home Based Trips (NHBT).approximately $85 \%$ of all trips are $(\mathrm{HBW})(6)$.

To examine the effects of various trip purpose categories on accuracy of prediction of trip generation studies were made for seven trip purposes which are:

2- $\quad$ Home-Based Work ( HBW );

3- $\quad$ Home-Based School ( HBS );

4- $\quad$ Home-Based College ( HBC );

5- $\quad$ Home-Based Shop ( $\mathrm{HBSH}$ );

6- Home-Based Other ( HBO ); and 
Table ( 1 ) Summary of Estimated Total Area-Wide of Trip Purpose and Split for the Study Area, Dohuk City, 2001.

\begin{tabular}{|c|c|c|c|c|c|c|c|c|c|c|}
\hline $\begin{array}{c}\text { Zone } \\
\#\end{array}$ & No. of & Total & Total & Total & HBS & HBC & HBW & HBSH & HBO & NHB \\
vehicle & private \\
trips & Trips & trips & trips & trips & trips & trips \\
\hline 1. & 995 & 8550 & 2522 & 2285 & 1852 & 394 & 3615 & 818 & 1487 & 236 \\
\hline 2. & 640 & 6160 & 1435 & 1791 & 1298 & 311 & 2724 & 539 & 859 & 283 \\
\hline 3. & 1273 & 10544 & 3066 & 4387 & 2109 & 1260 & 4472 & 1042 & 1951 & 388 \\
\hline 4. & 1570 & 12980 & 63040 & 3300 & 2620 & 700 & 5200 & 1340 & 2760 & 430 \\
\hline 5. & 262 & 2106 & 524 & 515 & 393 & 112 & 1104 & 159 & 131 & 19 \\
\hline 6. & 408 & 3505 & 874 & 1020 & 757 & 311 & 1651 & 301 & 291 & 49 \\
\hline 7. & 520 & 4200 & 630 & 1120 & 960 & 190 & 1890 & 240 & 590 & 330 \\
\hline 8. & 1200 & 8100 & 1190 & 620 & 3360 & 440 & 3380 & 380 & 570 & 60 \\
\hline 9. & 1120 & 8230 & 1470 & 560 & 3370 & 380 & 3640 & 330 & 540 & 120 \\
\hline 10. & 1550 & 12410 & 2460 & 2580 & 2540 & 470 & 5430 & 810 & 2220 & 920 \\
\hline 11. & 700 & 6370 & 1600 & 1480 & 750 & 180 & 2780 & 500 & 1530 & 620 \\
\hline 12. & 1160 & 10340 & 3020 & 1920 & 1000 & 260 & 4380 & 760 & 2760 & 1150 \\
\hline 13. & 583 & 4967 & 1691 & 1108 & 914 & 447 & 1604 & 340 & 457 & 389 \\
\hline 14. & 4505 & 35939 & 11695 & 10184 & 6690 & 2233 & 14932 & 3453 & 4889 & 2639 \\
\hline 15. & 884 & 7146 & 3146 & 2111 & 1206 & 402 & 3337 & 553 & 945 & 764 \\
\hline 16. & 1744 & 13707 & 6884 & 3176 & 2305 & 521 & 6653 & 952 & 1874 & 1403 \\
\hline 17. & 1350 & 10050 & 4290 & 3660 & 1870 & 1300 & 3920 & 850 & 1700 & 840 \\
\hline 18. & 1600 & 11577 & 5079 & 3393 & 2017 & 982 & 4279 & 832 & 1558 & 1355 \\
\hline 19. & 550 & 3710 & 1350 & 1540 & 710 & 200 & 1720 & 380 & 180 & 520 \\
\hline 20. & 1060 & 7160 & 2440 & 2990 & 1360 & 440 & 3240 & 820 & 320 & 1000 \\
\hline Total & 23678 & 187751 & 118406 & 49740 & 38081 & 11533 & 79951 & 15399 & 27702 & 13515 \\
\hline & & & & & & & & & \\
\hline
\end{tabular}


Al-Taei: Prediction Analvsis of Trip Production Using Cross-Classification

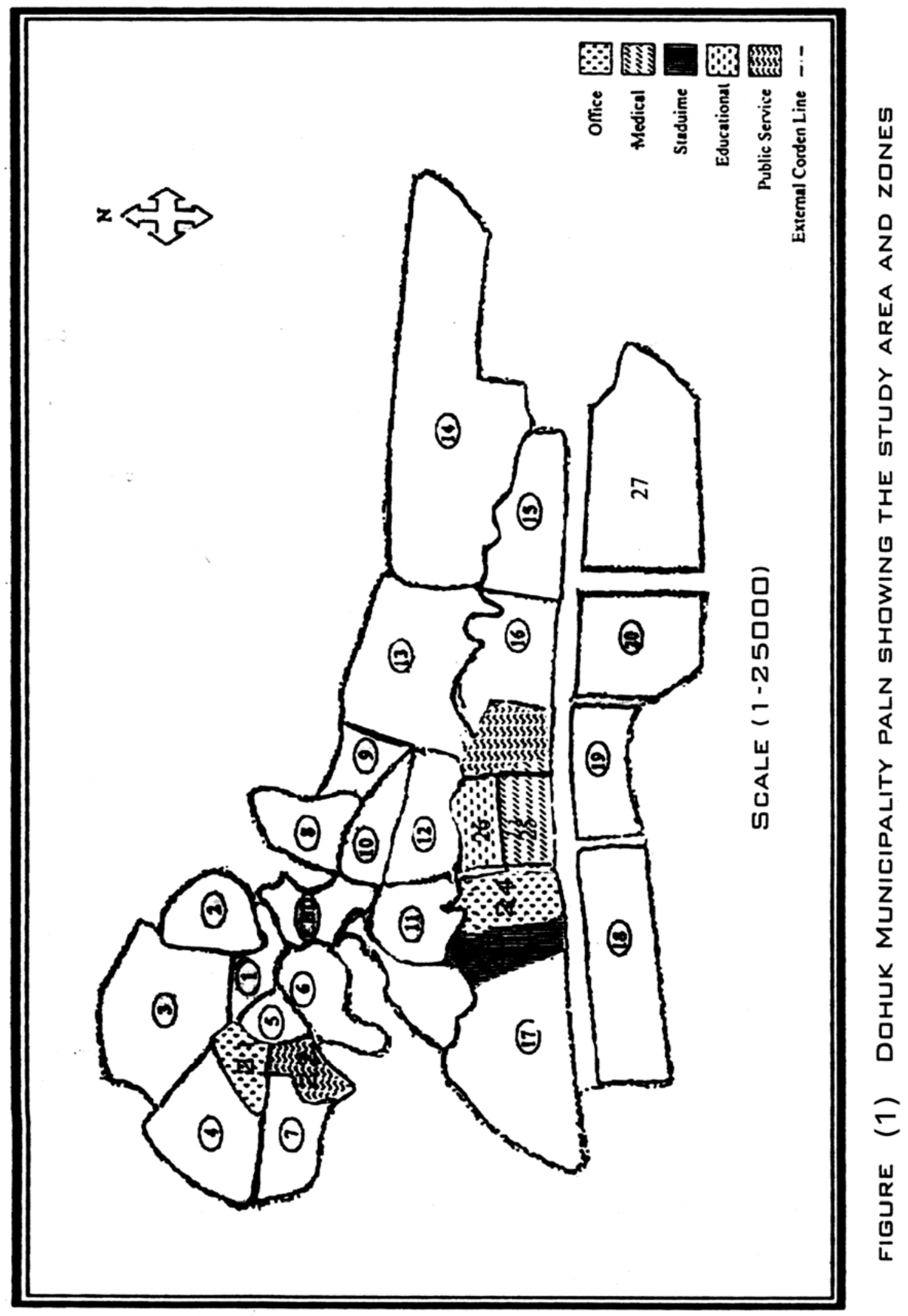




\section{\begin{tabular}{llll} 
Al-Rafidain Engineering & Vol.14 & No.4 & 2006 \\
\hline
\end{tabular}}

7- None Home-Based (NHB).

Development summary of trip data for the study area by purpose is shown in table (2) and obtained from preliminary analysis.

\section{Selection of Independent Variables}

An extensive review on some independent variables such as car ownership income level and household size at cross-classification analysis method is presented by various authors $(1,7,8)$.

Different trip purposes were also considered in the analysis which depends on the selection of the independent variable which is highly correlated with each dependent variable under analysis. Analysis procedure depends on the selection of the best two or three independent variables due to the narrow range of the independent variables used in each analysis run and more correlated from previous regression analysis and literature.

\section{Cross-Classification Program}

Cross-Classification analysis uses the household as the fundamental unit of trip generation process.

Description of that trip ( i.e., rates or frequency ) depends on household characteristics which includes these variables and mainly divided into small numbers of mutually exclusive and exhaustive classes such as: ID ;

Income class: $0-<1000,1000-<2000,2000-<3000, \ldots$ etc ( i.e., 6 to 7 classes )

$\mathrm{n}$ and

Cars owned : 0, 1,2+ (i.e., normally three categories to data collected);

Household size ; $3,4,5,6$, ...etc (i.e., normally 6 categories ).

\section{Cross Classification Matrix}

Cross classification contains rows and columns for each group of the matrix to describe its cross variables in cells. This was to give an indication about the average row or column values for each cell and also to give the total average of haul matrix. The values predicted should also be plotted and smooth curves be drawn through the data observations. It is considerably more difficult to provide zonal counts or forecasts of households in multi-dimensional cross-classification systems than in a one-way and simple two-way matrix.

Manipulation of SPSS package to obtain cross-classification matrix is possible after making some transformations and computations.

\section{Checks Required}

Cross-classification model is non-parametric and the usual test of significant and relative importance can not be made. However two points should be examined:

The number of observations for any cell of the matrix should be large enough for sufficient data or small enough so that there will be no variations in trip rates within the category. Many studies suggested that at least 25 observations must be accumulated in each cell otherwise the cell which has observations should be cars cell because car-ownership was considered as more significant in trip making than other variables; and 
Table ( 2 ): Three Dimensional Cross-Classification Matrix for Total Person Trips, Family Size with Income Group a Cross Car Ownership for Total Sample of the Study Area, Dohuk City, 2001.

\begin{tabular}{|c|c|c|c|c|}
\hline \multirow{2}{*}{ Income group } & \multirow{2}{*}{ Family size } & \multicolumn{3}{|c|}{ Cars ownership } \\
\hline & & 0 & 1 & $2+$ \\
\hline \multirow{7}{*}{$\begin{array}{c}\text { Low } \\
(0-2000)\end{array}$} & 3 & 7.07 & 5.2 & NA \\
\hline & 4 & 8.36 & 8.5 & NA \\
\hline & 5 & 11.77 & 11.92 & NA \\
\hline & 6 & 13.21 & 12.13 & NA \\
\hline & 7 & 17.64 & 15.33 & 16 \\
\hline & 8 & 16.49 & 11 & NA \\
\hline & $9+$ & 20.99 & 9.68 & NA \\
\hline \multirow{7}{*}{$\begin{array}{c}\text { Medium } \\
(2000-5000)\end{array}$} & 3 & 13.61 & 14.49 & NA \\
\hline & 4 & 16.29 & 11.73 & NA \\
\hline & 5 & 18.76 & 25.81 & NA \\
\hline & 6 & 22.24 & 22.44 & NA \\
\hline & 7 & 29.38 & 31.96 & NA \\
\hline & 8 & 27.87 & 18.04 & 12 \\
\hline & $9+$ & 41.4 & 35.93 & 30 \\
\hline \multirow{7}{*}{$\begin{array}{l}\text { High } \\
5000+\end{array}$} & 3 & 8 & 9.53 & NA \\
\hline & 4 & 14 & 10 & NA \\
\hline & 5 & 2 & 9.3 & NA \\
\hline & 6 & 17.50 & 15.57 & 12.89 \\
\hline & 7 & 29.50 & 20.98 & 12.14 \\
\hline & 8 & 14 & 20.12 & 7.00 \\
\hline & $9+$ & 19.82 & 29.86 & 22.00 \\
\hline
\end{tabular}




\section{\begin{tabular}{llll} 
Al-Rafidain Engineering & Vol.14 & No.4 & 2006 \\
\hline
\end{tabular}}

2- $\quad$ The cell values should not have too wide dispersion as reflected by the standard deviation of each value in the matrix. Many cells of the chosen crossclassification matrix had a large standard deviation of estimate as compared with the standard deviation of the mean variable. Consideration should be given to either stratifying of an additional variable or re-evaluating the initial choice of variable $(8,9)$.

\section{Cross-Classification Results}

Cross-classification is a dis- aggregated approach which is based on large sample of household ( $5000 \mathrm{HH}$ or more ), and travel behavior which uses data directly. There are savings in the amount of data required and some of the data can be transferred to other applications. The dis- aggregated approach expresses non-linear relationships and is more easily understood.

\section{Models Prediction}

One problem with the cross-classification technique is that, the independent variables may not be truly independent, and the resultant relationships and predictions may well be valid. In order to avoid that, the independent variables are taken from previous study (i.e., multiple regression), with car ownership, family size , and worker. These are the most important variables included as they are the basic core of household life cycle and economic variables to build the person trip crossclassification model. These variables are completely independent and non-collinear in nature to prevent invalidity.

\section{Family Size and Car Ownership}

Figure (2), up to figure ( 4 ), describe the relation of family size with three different types of trip rates with respect to three different levels of car ownership ( 0 , 1 , and $2+$ ).Trip rates are going to increase with the increase in family size with the direct increase in car owned by each family, except the total private trips / $\mathrm{HH}$ in figure ( 4 ), which shows no considerable increase, especially for (0), car ownership.

\section{Income Level and Car Ownership}

Income level was considered as an important characteristic in trip production prediction (10). Figure (5), up to figure (7) show the relationships between income level and three types of trip rates/Du. , for different car ownership. In general, the figures show direct increase in trip rates and family size at 0 , and 1 car ownership levels, but at $2+$ level it is going to decrease for moderate size family and increase for larger size one. Total vehicle trips/Du. for large family size it is going to decrease , especially for 2+ car ownership level.

\section{Worker Number and Car Ownership}

Number of workers in a family is the sum of worker number and employment number in a family as they have a great effect on the number of relationship generated as shown in figure ( 8 ), up to figure ( 10 ). The number of workers makes all type of trips to increase as it increase for different levels of car ownership, except for the 2+ level, especially in figure ( 9 ), which shows that the total vehicle trips /Du. is going to decrease as the worker number increase because the car is used by one or two members of the family only. 


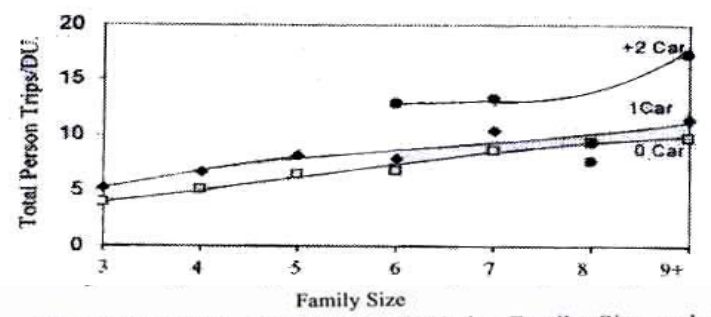

Figure( 2 ) Total Person Trips/DU. by Family Size and Car Ownership for Total Sample of the Study Area, Dohuk City,2001.

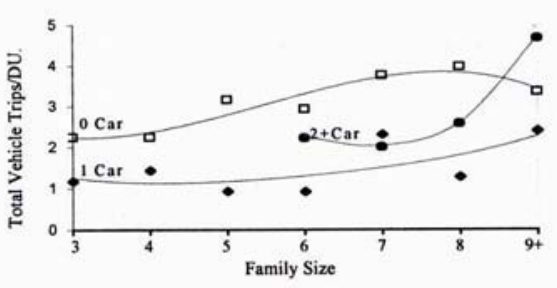

Figure( 3 ) Total Vehicle Trips/DU. by Family Size and Car Ownership for Total Sample of the Study Area, Dohuk City,2001.

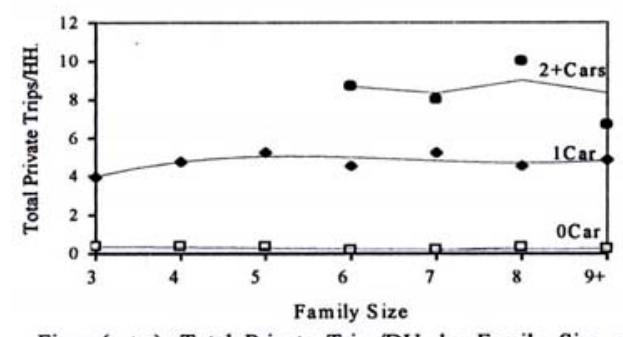

Figure( 4 ) Total Private Trips/DU. by Family Size and Car Ownership for Total Sample of the Study Area, Dohuk City,2001.

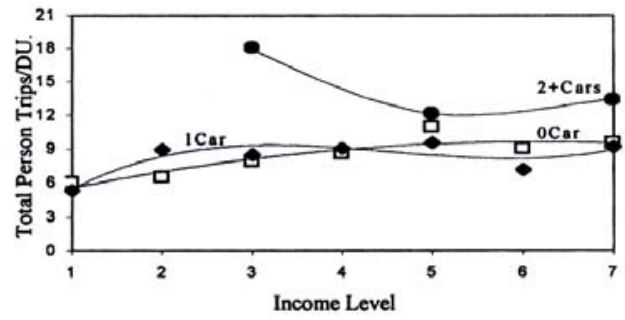

Figure( 5 ) Total Person Trips/DU.by Income Level and Car Ownership for Total Sample of the Study Area, Dohuk City, 2001.

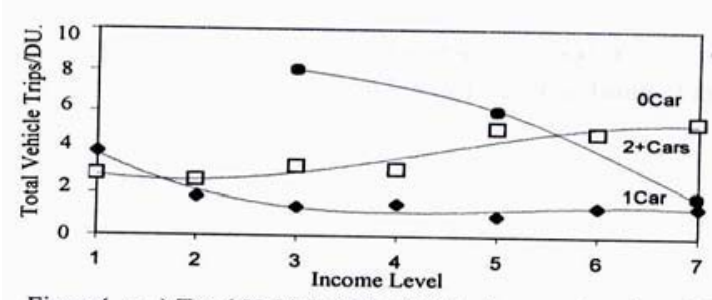

Figure ( 6 ) Total Vehicle Trips/DU.by Income Level and Ca Ownership for Total Sample of the Study Area, Dohuk City, 2001

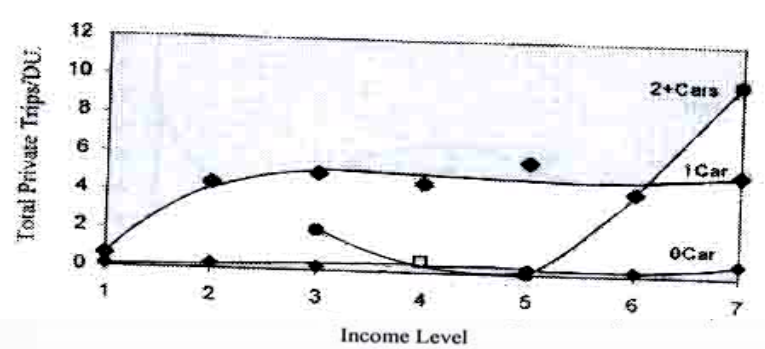

Figure ( 7 ) Total Piravte Trips/DU.by Income Level and Car Ownership for Total Sample of the Study Area, Dohuk City, 2001.

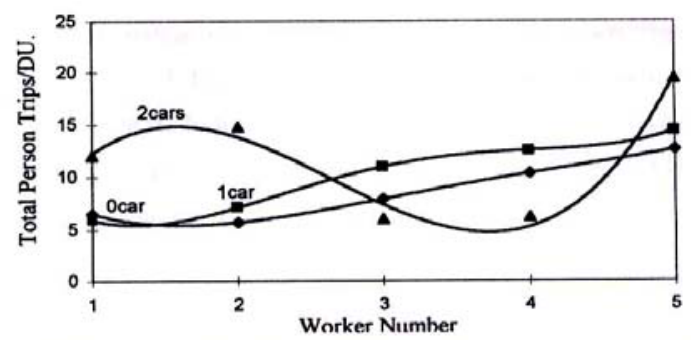

Figure ( 8 ) Total Person Trips/DU. by Worker Size and Car Ownership for Total Sample of the Study Area, Dohuk City,200]

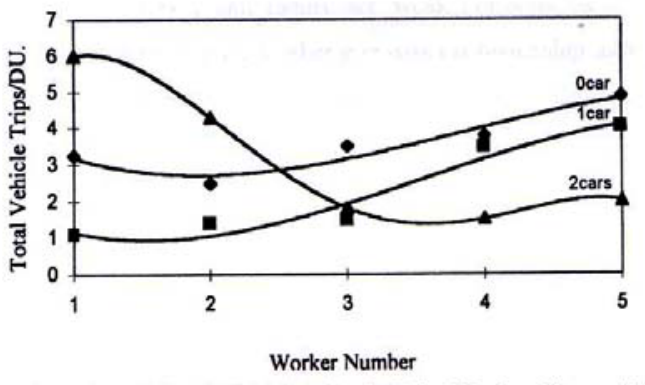

Figure( 9 ) Total Vehicle Trips/DU. by Worker Size and Car Ownership for Total Sample of the Study Area, Dohuk 2001. 


\section{\begin{tabular}{llll} 
Al-Rafidain Engineering & Vol.14 & No.4 & 2006 \\
\hline
\end{tabular}}

\section{Trip Production Prediction Model Procedure}

As noticed before, family size and number of workers in some way ,have the same effect on different trip mode purpose. Therefore, the prediction models procedure represented by numbers uses family size instead of both family size and workers. To predict family size and car ownership, sets of curves shown in figure ( 11 ), up to figure (13) can be used .These figures are to determine the trip generation production of residential zones. This procedure can be summarized as follows:

1- $\quad$ For figure (11), enter curve with family size to determine persons of dwelling units with 0,1 , and $2+$ or more car owned. Multiply by number of dwelling units to obtain number of household by car ownership class.

2- $\quad$ Enter curve shown in figure ( 12 ), with family size and number of dwelling units at 0,1 , and 2 or more cars owned to determine the person trips rate per dwelling unit and multiply the rate by the number of future households to obtain trips produced.

3- $\quad$ Enter figure (13), with family size and determine person trips by purpose (HBW , HBNW , and NHB ), and multiply by trips produced as calculated above to obtain trips produced by different purposes.

To give example to apply the above procedure zone number (1) from Table

(1) is selected with one thousand dwelling units with one car ownership category and five persons family size as future numbers.

1. Enter curve (11) with the above information to obtain a $(6 \%)$ of households working trips or $0.6 \times 1000=60$ houses owning one car in zone (1).

2. Enter curve (12) with the same above information to obtain a 7.5 total personal trips done by each household or $60 \times 7.5=450$ future trips will be generated from zone (1) for one car ownership category.

3. Enter curve (13) with the same above information too for the HBW work trip type. A six person trip is obtained for this trip purpose done by each household. Net number of HBW trips obtain for the one car ownership category in the future will be $0.06 \times 450=27$ trip only from zone (1). model.

This trip number will be used in the trip distribution matrix using gravity

This procedure also applied on figures ( 14 ), up to ( 16 ), which are specified for the curves of income level and cars owned. Income level effect is somewhat irregular here again, especially for total person trips, so it is found that some interpolation and interrelationships of the results were obtained 


\section{Special Model}

More complex classification system will in general explain more variance than simpler ones, the system degree (i.e level of classification increases) as the sample sizes of household within each cell increases. It was more sensitive and accurate than the previous two dimension matrix, but it is considerably more difficult to provide zonal counts of forecasts of households in multi-dimensional crossclassification systems than in one-way and simple two- way system ( 9 ).

Table ( 2 ), indicates the three way matrix of total person trips/ Du. and income level with family size across car ownership. The independent variable income level had been classified in its range shown in the table to three type low from $(0-<2000)$, medium from $(2000-<5000)$, and high for $(>5000)$. Table (2), listed the observations in each cell. It can be seen only cells for 2 cars owned or more contain very few observations. These cells values were ignored when plotting the matrix , and new values from smooth curve would be taken for the sub model later.

\section{Conclusions and Recommendations}

Out of the collected socio- economic data about different levels of families and under the cross-classification trip production analysis, the following conclusions can be drawn out:

1- In cross-classification modeling, data can be used directly with smaller number of observations required for that descriptions;

2- $\quad$ In building an effective cross-classification model, the most important variables to be considered are family size, car ownership , and workers;

3- $\quad$ Cross-classification prediction for family size are highly correlated with total person trips, and vehicle trips. For estimating total private trips, the income level yields better estimation than family size;

4- $\quad$ Largest sample sizes, as well as small number of categories in crossclassification matrix will reduce the number of invalid cells by introducing trip values place the cells. Also, interpolation between cells and combination among adjacent cells can be done for insignificant categories.

It can be recommended out of this study that, trip production matrix proposed in this study can be used in a comprehensive transportation study for Dohuk city mainly in the trip distribution UTP stage. 


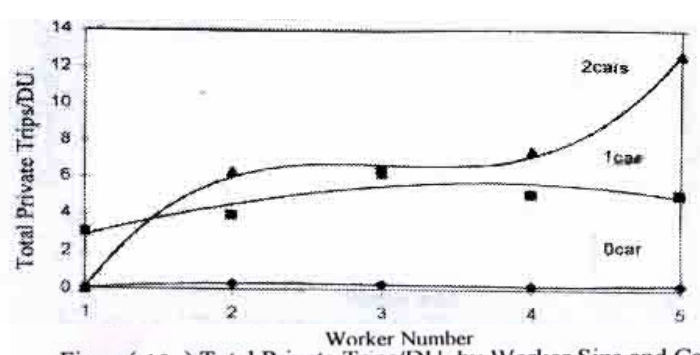

Worker Number
Figure( 10 ) Total Private Trips/DU. by Worker Size and Car Ownership for Total Smple of the Study Area, Dohuk 2001.

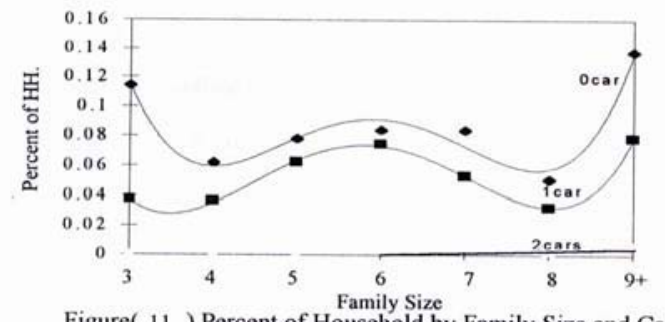

Figure( 11 ) Percent of Household by Family Size and Car Ownership Distribution, for the Study Area, Dohuk City,2001

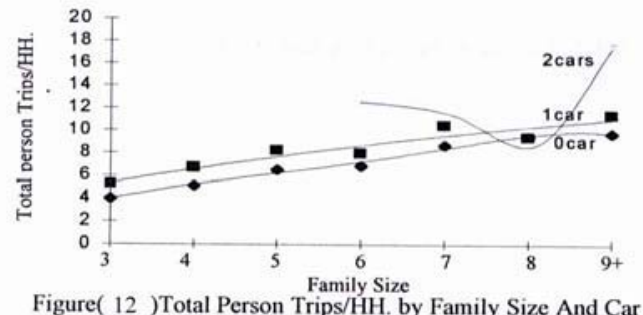

Figure( 12 )Total Person Trips/HH. by Family Size And Car Ownershipfor Total Sample of the Study Area,Dohuk City,2001.

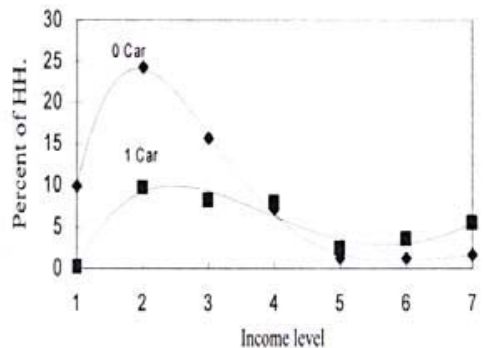

Figure( 14 ) Percent Household by Income and Canwnership Ditribution,for the Study Area,Dohuk,2001

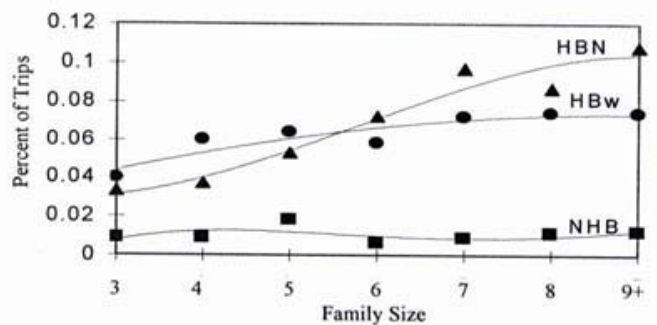

Figure( 13 )Percent of Trips by Family Size and Trip Purpose Disribution for the Study Area, Dohuk City, 2001

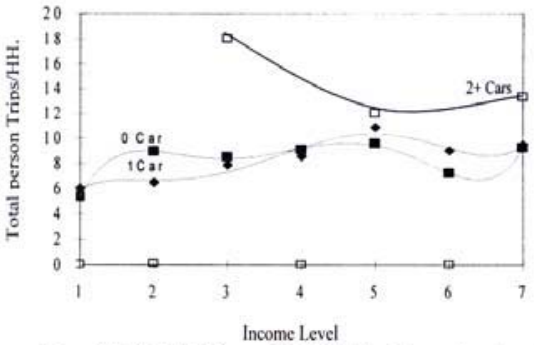

Figure( 15 ) Total Person Trips/HH. by Income Level and Car Ownershipfor the Study Area,Dohuk,2001.

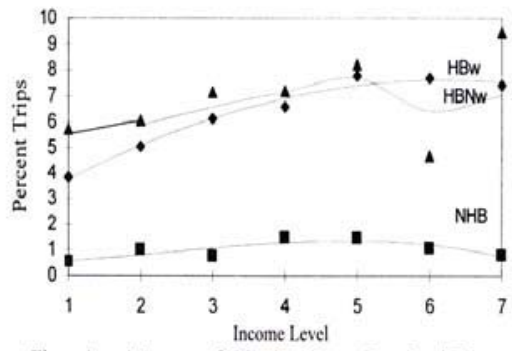

Figure( 16 ) Percent of Trips by Income Level and Trip Purpose Disribution for the Study Area, Dohuk, 2001 . 


\section{References}

1. Federal Highway Administration, "Trip Generation Analysis ", U.S., department of Transportation, Washington, December 1975.

2. Taha A.M., "Trip Production Analysis of Urban Area in Dohuk City "., M.Sc., thesis, Dohuk University 2002.

3. Traffic Control Office in Dohuk City, "Traffic Statistics", 1990-2000.

4. Garber, N.J., and, Hoel ,L. A. "Traffic and Highway Engineering ", Revised second edition, Pws, Pacific Grove CA 1999 .pp ( 545-560 ).

5. Metropolitan Transportation Commission", Sample Design for the 1990 Bay Area Household Travel Survey ", Working Paper \#1,1994.

6. $\quad$ Philomina , B.L. , and, Micheal J.D." Methodology for Non Work Travel Analysis in Suburban Communities ", Charlottes Suille Virginia, November, 1994.

7. Fong, L. and Jason, C. "Effect of Urban Character on Transferability of Travel Demand Models " National Academy of Science, Washington, D.C., 1982.

8. Federal Highway Administration, "Development and Application of Trip Generation Rates ", Final Report U.S. Development of Transportation, January 1985. http:// www.dot.gov.

9. Federal Highway Administration, "Model Development and Refinement Trip Generation ", Final Report, 1992.

10. Barard, P.O."An Examination of Home Interview Survey Trip ", Australian Road Research Board 15, March 1985 ,pp ( 41- 45 ). 